JURNAL
Nationally Accredited Journal Decree No. 36/E/KPT/2019, Dated 13rd December 2019
http://ejournal.sthb.ac.id/index.php/jwy
Vol. 4 I No. $\mid$ Maret 2020 Halaman : 63-79

\title{
Upaya Penguatan Badan Penelitian dan Pengembangan serta Inovasi Daerah di Kota Palopo
}

\author{
Rahman Syamsuddin ${ }^{1}$, Muhammad Ikram Nur Fuady ${ }^{2}$ \\ ${ }^{1,2}$ Fakultas Hukum, Universitas Islam Negeri Alauddin, Makassar, Indonesia \\ $\bowtie$ Corresponding Author: ikram.nurfuady@uin-alauddin.ac.id
}

\section{Info Artikel:}

DOI: $10.25072 /$ jwy.v4i1.326

Diterima: 8 Januari 2020 I Disetujui: 31 Maret 2020 IDipublikasikan: 10 April 2020

Kata Kunci:

Balitbangda; Inovasi

Daerah; Kota Palopo;

Penelitian dan

Pengembangan.

\begin{abstract}
Abstrak
Pemerintah Daerah Kota Palopo memiliki wewenang dalam berinisiatif, mengelola, dan mengoptimalkan potensi sumber daya serta mengatur arah pembangunan daerah untuk menyejahterahkan masyarakat. Hal tersebut dapat terwujud dengan pemenuhan pengembangan inovasi melalui penguatan peran badan penelitian dan pengembangan daerah (Balitbangda). Tujuan penelitian ini adalah untuk mengetahui sasaran, jangkauan, dan arah pengaturan yang perlu diatur dalam rancangan peraturan daerah tentang peran Balitbangda terkait kewenangan pemerintah daerah dalam kegiatan penelitian, pengembangan, serta pengembangan inovasi. Penelitian ini bersifat deskriptif dengan jenis penelitian yuridis normatif-empiris dengan sumber data melalui studi kepustakaan dan diskusi kelompok terpumpung. Metode pendekatan menggunakan pendekatan peraturan perundang-undangan dan pendekatan konseptual yang dianalisis secara kualitatif. Hasil penelitian memperlihatkan pemberian ruang untuk interaksi dan kolaborasi pelaku inovasi, percepatan koordinasi dan intermediasi antara stakeholder dalam pemanfaatan hasil penelitian dan pengembangan dapat lebih optimal dengan hadirnya peraturan daerah tentang kegiatan penelitian dan pengembangan yang memperkuat Balitbangda.
\end{abstract}

Keywords:

Balitbangda; Palopo City; Regional Innovation; Research and Development.

\begin{abstract}
The Regional Government of Palopo City has the authority to initiate, manage, and optimize the resources and regional development for the welfare of its people. It can be realized by fulfillment of innovation development through strengthening the role of Regional Research and Development Agency (Balitbangda). The aim of this research was to determine the target, scope, and direction of regulation in draft regional regulation on the role of the Balitbangda related in research, development and innovation development activities. This research is descriptive research with normative-empiric juridical type, while data sources through literature studies and focus group discussion. The method of approach used are statute approach and conseptual approach, then analyzed qualitatively. The results showed that appropriation room for interaction and collaboration among innovators, accelerated of coordination and intermediation between stakeholders in utilization of research and development results can be optimized by presence of regional regulations that strengthening Balitbangda.
\end{abstract}




\section{A. PENDAHULUAN}

Undang-Undang Nomor 9 Tahun 2015 tentang Perubahan Kedua atas Undang-Undang Nomor 23 Tahun 2014 tentang Pemerintahan Daerah mengamanatkan bahwa otonomi daerah adalah hak, wewenang, dan kewajiban daerah otonom untuk mengatur dan mengurus sendiri urusan pemerintahan dan kepentingan masyarakat setempat sesuai dengan peraturan perundangundangan. Artinya pemerintah daerah mempunyai hak dan wewenang untuk membuat inisiatif sendiri, mengelola, dan mengoptimalkan potensi sumber daya, serta mengatur arah pembangunan daerah sesuai dengan peraturan perundang-undangan yang berlaku. Akan tetapi, pada dasarnya kewenangan tersebut adalah pelimpahan kewenangan pemerintah pusat kepada pemerintah daerah. ${ }^{1}$

Sehubungan dengan hal tersebut, secara struktural pemerintah daerah tetap berada pada koordinasi pemerintah pusat. Kebijakan pemerintah pusat memberikan kewenangan yang lebih luas kepada tiap pemerintah daerah adalah bentuk tanggung jawab pemerintah terhadap pelayanan masyarakat dalam membangun dan mengatur daerah masing-masing dari aspek pembangunan maupun pengaturan tatanan kehidupan masyarakat daerah dalam mengaplikasikan tuntutan era globalisasi. ${ }^{2}$ Pada akhirnya, kemajuan dan kemunduran pemerintah daerah dalam merespon perkembangan secara global ditentukan oleh kemampuan daerah itu sendiri. Selain memiliki fungsi utama, daerah juga memiliki fungsi penunjang untuk urusan yang menjadi kewenangannya. ${ }^{3}$

Pelaksanaan fungsi penunjang urusan pemerintahan yang menjadi kewenangan daerah di provinsi dan kabupaten/kota, adalah melalui pembentukan "badan". Salah satunya meliputi badan yang melaksanakan fungsi penelitian dan pengembangan. Daerah mempunyai hak dan wewenang serta kewajiban dalam mengatur dan mengurus sendiri urusan pemerintahan dan kepentingan masyarakatnya. Otonomi daerah dilaksanakan menurut prakarsa sendiri berdasarkan aspirasi

1 Reynold Simandjuntak, "Sistem Desentralisasi Dalam Negara Kesatuan Republik Indonesia Perspektif Yuridis Konstitusional," Journal de Jure 7, No. 1 (2016): 57-67, https://doi.org/10.18860/jfsh.v7i1.3512, hlm. 59.

2 Doo-Rae Kim and Jong-Han Yoon, “Decentralization, Government Capacity, and Environmental Policy Performance: A Cross-National Analysis," International Journal of Public Administration 41, No. 13 (October 3, 2018): 106-171, https://doi.org/10.1080/01900692.2017.1318917, hlm. 158.

3 Thomas B. Pepinsky and Maria M. Wihardja, "Decentralization and Economic Performance in Indonesia," Journal of East Asian Studies 11, No. 3 (2011): 337-371, https://doi.org/10.1017/ S1598240800007372, hlm. 363. 
masyarakat sesuai dengan prinsip otonomi seluas-luasnya dalam sistem dan prinsip NKRI. ${ }^{4}$

Urgensi inovasi tersebut juga diperlukan oleh Kota Palopo sendiri yang memiliki luas wilayah $258 \mathrm{~km}^{2}$ yang terbagi ke dalam 9 kecamatan dan 48 kelurahan. Adapun jumlah penduduk 178.906 jiwa, laju pertumbuhan 2,31\%, dengan kepadatan penduduk 715 jiwa/ $\mathrm{km}^{2}$ serta tingkat peningkatan ekonomi lebih dari $7 \%$ per tahun. Dari luasnya wilayah dan perkembangan ekonomi yang cepat ini dibutuhkan suatu rencana pengembangan secara luas, salah satunya dengan penguatan badan penelitian dan pengembangan daerah (Balitbangda) dan inovasi daerah. ${ }^{5}$

Pengembangan Balitbangda serta inovasi daerah merupakan semangat dari visi dan misi Kota Palopo 2018-2023, yakni “Terwujudnya Palopo Sebagai Kota Maju, Inovatif, dan Berkelanjutan pada Tahun 2023". Maju, dalam hal ini bermakna bahwa kota harus bergerak ke arah yang lebih positif, yang dibuktikan dengan ketersediaan sarana dan prasarana perkotaan yang lengkap, lebih berkualitas, dan bermanfaat bagi kehidupan ekonomi dan kesejahteraan warganya. Inovatif, berarti Palopo yang inovatif, berarti kota ini selalu memberikan solusi terhadap persoalan warganya melalui pengelolaan pemerintahan dan layanan publik yang efisien, efektif, dan berbasis riset, serta industri kreatif berkembang sebagai sektor utama penggerak ekonomi. Berkelanjutan, bermakna bahwa pembangunan dilakukan secara harmonis sesuai daya dukung dan daya tampung lingkungan hidup, inklusif secara sosial dan memperlihatkan kelestarian budaya lokal. Palopo maju, inovatif, dan berkelanjutan bermakna: Palopo memiliki visi dalam pembangunan sarana dan prasarana perkotaan yang memberi dampak positif dalam perekonomian dan kesejahteraan rakyat, penyelenggaraan pemerintahan yang efektif dan pengembangan ekonomi kreatif, namun tetap memperhatikan keseimbangan lingkungan dan kondisi budaya. $^{6}$

Upaya dalam mewujudkan visi Kota Palopo, banyak hal yang harus dilakukan seperti pengembangan Balitbangda dan sistem inovasi daerahnya yang harus berpegang pada landasan hidup masyarakat Sulawesi Selatan yaitu,

4 Jorawati Simarmata, "Politik Hukum Restrukturisasi Pembentukan Perangkat Daerah Pasca Reformasi (Sekilas Tanggapan Terhadap Peraturan Pemerintah Nomor 18 Tahun 2016 Tentang Perangkat Daerah) (Political Law of Post-Reformation Local Government Officers Restructuring/ Formin," Legislasi Indonesia 13, No. 4 (2016): 347-358, hlm. 350.

5 Pemerintah Kota Palopo, “Profil Kota Palopo," https://palopokota.go.id/page/visi-dan-misi, accessed January 7, 2020.

$6 \quad$ Ibid., hlm. 2. 
Siri' Na Pacce. Hal ini agar kebijakan atau arah pembangunan yang diambil dapat diterima oleh masyarakat dengan baik. ${ }^{7}$ Pengembangan inovasi Kota Palopo diharapkan mampu menjawab dan mengatasi beberapa isu strategis seperti aspek lingkungan hidup terkait ancaman menurunnya kualitas lingkungan perkotaan, aspek ekonomi, dan kesejahteraan rakyat di mana melemahnya kualitas hidup dan sendi ekonomi warga, dan aspek sumber daya manusia (SDM) yang telah berkembang dari aspirasi dan kreativitas warga yang perlu mendapat salurannya.

Proses memajukan Balitbangda serta inovasi daerah, maka perlu memperhatikan kondisi saat ini di Kota Palopo. Adapun keadaan saat ini yang perlu ditingkatkan yakni: 1) Belum ada SDM fungsional litbang di Kota Palopo; 2) Kemampuan Balitbangda dalam melaksanakan riset yang masih terbatas adalah hal yang sangat penting untuk segera ditingkatkan, mengingat layanan utama Balitbangda Kota Palopo yaitu pelaksanaan penelitian dan pengembangan daerah; 3) Keterlibatan Balitbangda dalam penentuan kebijakan daerahyang masih rendah perludidorong dengan koordinasi dan sosialiasi tentang peran Balitbangda dalam penyusunan kebijakan daerah; 4) Balitbangda Kota Palopo belum memiliki perangkat litbang yang dapat menilai/mereview kualitas litbang yang telah dihasilkan; 5) Belum adanya jurnal yang dikelola Balitbangda untuk media publikasi; 6) Belum ada mekanisme/regulasi yang mendorong peran Balitbangda dalam mendorong sebuah rekomendasimenjadi kebijakan; 7) Kemampuan Balitbangda untuk memfasilitasi perangkat daerah untuk berinovasi masih rendah dapat ditingkatkan dengan membentuk forum koordinasi litbang daerah Kota Palopo di mana seluruh perangkat daerah didorong dan difasilitasi untuk berinovasi sehingga pelayanan publik semakin berkualitas; 8) Belum adanya kebijakan/regulasi/pedoman penyelenggaraan inovasi daerah berimplikasi pada adanya inkonsistensi arah kebijakan sistem inovasi daerah; 9) Belum adanya regulasi daerah yang mempertegas peran Balitbangda dalam mengawal inovasi yang diusulkan menjadi kebijakan daerah. ${ }^{8}$

Oleh karena itu, penelitian ini bertujuan untuk mengetahui sasaran, jangkauan, dan arah pengaturan yang perlu diatur dalam Rancangan Peraturan Daerah (Raperda) tentang peran Balitbangda terkait kewenangan

\footnotetext{
Muhammad Ikram dan Nur Fuady, "Siri ' Na Pacce Culture in Judge' s Decision (Study in Gowa , South Sulawesi Province)," Fiat Justisia 13, No. 3 (2019): 241-254, https://doi.org/10.25041/fiatjustisia. v13no3.1684, hlm. 242-243.

8 Hasil Focus Group Discussion, “Kondisi Saat Ini Kota Palopo” (2019) oleh Pemerintah Kota Palopo.
} 
pemerintah daerah dalam kegiatan penelitian, pengembangan, serta pengembangan inovasi. Hal tersebut dilatarbelakangi oleh: 1) Pesatnya perkembangan teknologi dan informasi secara global belum bisa diikuti dengan perkembangan riset dalam negeri dan daerah, khususnya Kota Palopo. Praktik desentralisasi didorong untuk penguatan lembaga Balitbangda serta peningkatan inovasi daerah Kota Palopo; 2) Regulasi seperti peraturan daerah dibutuhkan dalam rangka memaksimalkan peran pemerintah daerah Kota Palopo dalam mengorganisir Balitbangda dan meningkatkan sistem inovasi daerah; 3) Demi kesejahteraan masyarakat di daerah, utamanya pemenuhan pengembangan inovasi dan peningkatan kesejahtraan, maka dibutuhkan penanganan serius dari pemerintah daerah untuk mengatur antusiasme masyarakat di Kota Palopo dalam hal litbang dan penguatan sistem inovasi daerah. Apalagi terdapat kewenangan yang diberikan kepada pemerintah daerah yang dijamin oleh konstitusi dan aturan perundang-undangan; 4) Sasaran, ruang lingkup, arah pengaturan, dan substansi muatan yang perlu diatur dalam Raperda kelitbangan dan sistem inovasi daerah ini terkait kewenangan pemerintah daerah, penelitian, pengembangan, pengkajian, dan/atau penerapan. ${ }^{9}$

Peningkatan Balitbangda dan inovasi daerah juga penting dalam perkembangan dunia hukum. Hasil penelitian, pengembangan, dan inovasi tersebut dapat menjadi acuan dalam menentukan kebijakan daerah serta mudah diaplikasikan karena berbasis kebutuhan daerah. Berbagai kebijakan dan peraturan daerah konstruktif dapat lahir demi mensejahterahkan masyarakat.

\section{B. METODE PENELITIAN}

Penelitian ini bersifat deskriptif dengan jenis penelitian yuridis normatifempiris terhadap data primer dilapangan dan peraturan perundang-undangan yang terkait. Kemudian metode pendekatan yang digunakan adalah pendekatan perundang-undangan (statute approach) dan pendekatan konseptual (conceptual approach). Teknik pengumpulan data menggunakan studi kepustakaan dan partisipatif berupa diskusi kelompok terpumpung (focus group discussion) dengan studi dokumen. Metode analisis data menggunakan analisis kualitatif yang dilakukan dengan cara mendeskripsikan dan mengambil simpulan dari hasil penelitian di

Hasil Focus Group Discussion dengan Stakeholder, “Urgensi Penguatan Balitbangda Dan Inovasi Daerah" (2019) oleh Pemerintah Kota Palopo. 
lapangan dengan stakeholder terhadap peraturan perundang-undangan terkait, mulai dari pemerintah daerah Kota Palopo, Forum Koordinasi Pimpinan Daerah (Forkopimda) Kota Palopo, Balitbangda Kota Palopo, universitas di Kota Palopo, dan masyarakat di Kota Palopo.

\section{HASIL DAN PEMBAHASAN}

1. Sasaran Peningkatan Peran Balitbangda

Sasaran peningkatan peran Balitbangda adalah aspek inovasi di daerah. Inovasi adalah hasil pemikiran, penelitian, pengembangan, pengkajian, dan/atau penerapan yang mengacu pada unsur kebaruan dan telah diterapkan serta memberikan kemanfaatan, ekonomi, dan atau sosial. ${ }^{10}$ Inovasi, menurut Said diartikan sebagai suatu perubahan yang terencana dengan menggunakan teknologi dan peralatan baru pada lingkup instansi. ${ }^{11}$ Inovasi tidak hanya memiliki pengertian sebatas membangun dan memperbaharui, tetapi juga dapat diartikan secara luas sebagai memanfaatkan ide-ide baru dalam menciptakan produk, proses, dan layanan. ${ }^{12}$ Menurut Hamel, inovasi dimaknai sebagai peralihan dari prinsip, proses, dan praktik manajemen tradisional atau perubahan dari bentuk yang lama dan memberi efek yang siginifikan terhadap cara sebuah majanemen yang dijalankan. ${ }^{13}$

Greg Richards dan Julie Wilson juga memberikan gambaran bahwa inovasi merupakan suatu pengenalan penemuan baru atau menyebarkan makna penemuan baru tersebut ke dalam penggunaan umum di masyarakat. Inovasi produk tidak harus datang dari pimpinan saja, tetapi harus dari semua pihak yang terlibat dalam proses produksi. Inovasi dapat dimaknai sebagai kreasi dan aplikasi kombinasi baru. Inovasi memiliki arti pengembangan dan implementasi sesuatu yang baru. ${ }^{14}$

Menurut Alan William dalam bukunya Creativity, Invention and Innovation sebagaimana dikutip Nana:

"Innovation can be described as the art of applying the new and the better, and more spesifically the process by which entrepreneurs are catalyst for change by converting opportunities into marketable realities." 15

\footnotetext{
10 Pasal 1 angka 13 Undang-Undang Nomor 11 Tahun 2019 tentang Sistem Nasional Ilmu Pengetahuan Dan Teknologi.

11 M. Mas'ud Said, Birokrasi Di Negara Birokratis (Malang: UMM Press, 2007), hlm. 27.

12 Susanto, "60 Management Gems," Kompas, 2010, hlm. 158.

13 Hamel dalam Djamaludin, Kepemimpinan Dan Inovasi (Jakarta: Erlangga, 2012), hlm. 34.

14 Richards dan Wilson dalam Purwanto and Zakaria Lantang Sukirno, "Inovasi Produk Dan Motif Seni Batik Pesisiran," Jurnal Al-Azhar Indonesia Seri Pranata Sosial 1, No. 4 (2012): 217-229, hlm. 219.

15 William dalam Nana Herdiana, Manajemen Bisnis Syariah Dan Kewirausahaan (Bandung: Pustaka Setia, 2013), hlm. 209.
} 
Berdasarkan pandangan beberapa ahli di atas, dapat kita lihat bahwa inovasi merupakan suatu proses yang terencanakan, berawal dari hasil pemikiran, penelitian, pengembangan, pengkajian, dan penerapan yang memiliki unsur kebaharuan berupa produk, jasa, dan yang lainnya dan dapat membantu mengatasi berbagai masalah.

Penemuan inovasi dalam perkembangannya memiliki beberapa poin penting yang dapat menunjukkan suatu organisasi yang melakukan inovasi. Menurut Suwarno, ada lima hal yang harus dan perlu ada pada suatu inovasi sebagaimana berikut ini: 1) Sebuah inovasi hadir sebagai pengetahuan baru bagi masyarakat dalam sebuah sistem sosial tertentu.Pengetahuan barutersebut adalah faktor utama yang menandakan perubahan sosial di masyarakat; 2) Cara baru. Inovasi dapat juga berupa cara baru bagi individu atau sekelompok orang untuk memenuhi kebutuhan atau menjawab masalah tertentu; 3) Objek baru, merupakan suatu inovasi merujuk pada hadirnya objek baru untuk penggunanya. Objek baru ini bisa dalam bentuk fisik atau tidak berwujud fisik; 4) Teknologi baru, merupakan inovasi sangat identik dengan kemajuan teknologi. Banyak contoh inovasi yang muncul dari hasil kemajuan teknologi.
Indikator kemajuan dari suatu produk teknologi yang inovatif biasanya dapat dilihat dari aplikasi yang disediakan oleh produk tersebut; 5) Penemuan baru, adalah hasil semua inovasi. Inovasi merupakan produk dari sebuah proses yang bekerja dengan maksimal ditambah kesadaran dan antusiasnya. ${ }^{16}$

\section{Jangkauan Balitbangda dalam Peningkatan Inovasi Daerah}

a. Jenis Inovasi Daerah

Proses inovasi adalah proses yang bersifat kompleks dan tidak bisa dianggap sederhana, meskipun dengan memberikan suatu unsur yang baru. Namun, hal tersebut memerlukan aspekaspek lain dalam konteks organisasi pada sektor publik atau organisasi pemerintahan yang meliputi hadirnya proses politik, kebijakan, kualitas, dan semacamnya. Menurut Mulgan dan Albury, suatu inovasi dapat dikatakan berhasil, jika inovasi tersebut adalah kreasi dan pelaksanaan dari proses, produk, layanan, dan metode pelayanan baru. Kemudian semua hal tersebut merupakan hasil pengembangan nyata demi mendapat efisiensi dan efektivitas yang lebih baik. ${ }^{17}$

Inovasi tidak hanya dalam lingkup produk dan pelayanan saja. Inovasi produk dan layanan meliputi

\footnotetext{
16 Suwarno Yogi, Inovasi Di Sektor Publik (Jakarta: STIA LAN, 2008), hlm. 8.

17 Mulgan dan Albury dalam M.R. Khairul Muluk, Knowledge Management (Kunci Sukses Inovasi Pemerintah Daerah) (Malang: Banyumedia, 2008), hlm. 44.
} 
perubahan bentuk dan desain produk atau lainnya. Sedangkan proses berasal dari gerakan pembaharuan kualitas yang berkelanjutan dan berpedoman pada kombinasi perubahan organisasi, prosedur, dan kebijakan yang relevan dengan inovasi tersebut. Jenis-jenis inovasi pada organisasi sektor publik menurut Muluk adalah sebagai berikut: 1) Inovasi produk, yaitu inovasi yang berawal dari perubahan pada desain dan produk suatu layanan dengan memisahkan dengan produk layanan sebelumnya; 2) Inovasi proses, yaitu inovasi yang ditandai dengan pembaharuan kualitas yang berkelanjutan dan perpaduan antara perubahan, prosedur, kebijakan, dan manajemen yang diperlukan organisasi; 3) Inovasi metode pelayanan, yaitu inovasi dengan hadirnya perubahan yang baru dalam aspek interaksi yang dilakukan pelanggan atau cara baru dalam menyediakan atau memberikan layanan; 4) Inovasi strategi atau kebijakan, yaitu inovasi yang melihat pada aspek visi, misi, tujuan, dan strategi baru serta menyangkut realitas yang ada, sehingga diperlukan suatu strategi dan kebijakan baru; dan 5) Inovasi sistem, yaitu kebaruan dalam konteks interaksi atau hubungan yang dilakukan dengan pihak aktor lain dengan tujuan melahirkan perubahan pengelolaan organisasi. $^{18}$

Berdasarkan penjelasan tersebut, dapat diketahui bahwa terdapat beberapa jenis inovasi dalam sektor publik yang terdiri dari inovasi produk layanan, inovasi proses, inovasi dalam metode pelayanan, inovasi dalam strategi atau kebijakan, dan inovasi sistem. Hal ini menggambarkan bahwa inovasi memiliki tipe atau jenis yang bermacam-macam.

\section{b. Kegiatan Penelitian dan \\ Pengembangan \\ Penelitian adalah kegiatan yang} dilakukan menurut kaidah dan metode ilmiah secara sistematis guna mendapatkan informasi, data, dan keterangan yang bertautan dengan pemahaman dan pembuktian kebenaran atau ketidakbenaran suatu asumsi dan/ atauhipotesisdibidangilmupengetahuan dan teknologi yang berhubungan dengan penyelenggaraan pemerintahan, baik dalam negeri maupun pemerintahan daerah (berdasarkan Pasal 1 angka 1 Peraturan Menteri Dalam Negeri Republik Indonesia Nomor 17 Tahun 2016 tentang Pedoman Penelitian dan Pengembangan di Kementerian Dalam Negeri dan Pemerintahan Daerah).

Pengembangan merupakan kegiatan ilmu pengetahuan dan teknologi yang

$18 \quad$ Ibid., hlm. 50. 
bertujuan menggunakan prinsip dan teori ilmu pengetahuan yang terbukti kebenarannya untuk meningkatkan fungsi, manfaat, dan aplikasi ilmu pengetahuan yang sudah ada, atau melahirkan teknologi baru yang berhubungan dengan penyelenggaraan pemerintahan, baik dalam negeri dan daerah sebagaimana Pasal 1 Angka 3 Permendagri Nomor 17 Tahun 2016 tentang Pedoman Penelitian dan Pengembangan di Kementerian Dalam Negeri dan Pemerintahan Daerah.

Kegiatan penelitian dan
pengembangan atau research and
development activities merupakan metode yang dapat digunakan untuk menguji efektivitas suatu produk yang dihasilkan. Menurut Borg \& Gall, penelitian dan pengembangan merupakan suatu proses yang digunakan guna mengembangkan dan melakukan validasi terhadap produk pendidikan. ${ }^{19}$ Menurut Seels \& Richey bahwa penelitian dan pengembangan adalah kajian yang dilakukan dengan mengikutisuatu proseduryang sistematis untuk merancang, mengembangkan, dan evaluasi terhadap program, proses, dan hasil pembelajaran yang harus sesuai dengan kriteria konsistensi dan keefektifan internal. ${ }^{20}$

Tujuan dari penelitian dan pengembangan adalah:1)Menilai perubahan yang terjadi dalam kurun waktu atau periode tertentu dan 2) Menghasilkan suatu produk baru melalui proses pengembangan. ${ }^{21}$

\section{Landasan dan Arah Pengaturan yang Perlu Diatur dalam Rancangan Peraturan Daerah tentang Peran Balitbangda}

\section{a. Landasan Filosofis}

Landasan filosofis ini berkenaan dengan nilai-nilai yang menurut teori hukum ada 3 (tiga) nilai yang utama yaitu; nilai keadilan, nilai kepastian hukum, dan nilai kemanfaatan. ${ }^{22}$ Nilainilai ini sudah barang tentu berlaku pula dalam bidang inovasi daerah yang menjadi fokus pada naskah akademik ini yaitu peningkatan sistem inovasi daerah. Dasar filosofis pembuatan peraturan daerah tentang peningkatan inovasi daerah pada hakikatnya berkaitan dengan pengamalan dari tujuan negara, yakni memajukan kesejahteraan umum, mencerdaskan kehidupan bangsa.

19 Borg \& Gall dalam Punaji Setyosari, Metode Penelitian Pendidikan Dan Pengembangan (Jakarta: Kencana, 2018), hlm. 194.

20 Seels \& Richey dalam Ibid, hlm 195.

21 Ibid., hlm. 200.

22 Ibnu Artadi, "Hukum : Antara Nilai-Nilai Kepastian, Kemanfaatan Dan Keadilan," Hukum Dan Dinamika Masyarakat 4, No. 1 (2006): 67-81, https://doi.org/http://dx.doi.org/10.36356/hdm.v4i1.362, hlm. 67. 
Dalam mencapai kesejahteraan umum diperlukan suatu sistem yang dapat menjadi tumpuan dari pemimpin dalam mengeluarkan kebijakan. Kebijakan sendiri haruslah bersumber pada suatu hasil penelitian atau riset. Pentingnya hasil penelitian dan pengembangan bertujuan mendorong inovasi-inovasi dalam meningkatkan kesejahteraan masyarakat atau kesejahteraan umum.

\section{b. Landasan Sosiologis}

Sistem inovasi daerah harus mampu menjamin peningkatan kesejahteraan warga, peningkatan mutu dan perbaikan manajemen penelitian dan pengembangan. Peningkatan sistem inovasi daerah ini sebagai jalan dalam menghadapi tantangan sesuai dengan tuntutan perubahan kehidupan lokal, nasional, dan global, sehingga diperlukan pembaharuan pendidikan secara terencana, terarah, dan berkelanjutan. Pemerintah pusat dan pemerintah daerah dalam menyelenggarakan suatu system inovasi harus memiliki tujuan yang sama, sehingga hasil riset dapat menjadi tumpuan birokrasi dan masyarakat. ${ }^{23}$

Selain itu, aspek sosiologis yakni meningkatkan pelayanan publik dan menciptakan kebijakan publik yang berkualitas serta tanggap terhadap kebutuhan masyarakat berdasarkan pengembangan ilmu pengetahuan, produktivitas, dan daya saing, perlu didukung oleh suatu peraturan daerah tentang kebijakan inovasi di daerah. ${ }^{24}$

Perkembangan daerah-daerah didukung dengan beragamnya inovasi yang dihasilkan merupakan harapan bersama, agar apa yang menjadi keinginan dan aspirasi masyarakat bisa terpenuhi. Aspirasi dan kebutuhan masyarakat menjadi bagian penting dalam inisiasi peraturan perundangundangan, pada tingkat nasional dan daerah. Kebutuhan setiap daerah berbeda dengan daerah lainnya. Aspirasi masyarakat inilah yang menjadi dasar dalam proses lahirnya suatu peraturan daerah yang akan mengatur hasil inovasi, khususnya litbang dan inovasi daerah.

\section{c. Landasan Yuridis}

Balitbangda sebagai pelaksana teknis yang membantu kepala daerah dalam mengkoordinasikan pelaksanaan inovasi guna peningkatan daya saing daerah. Undang-Undang Nomor 15 Tahun 2019 tentang Perubahan atas Undang-Undang

23 Teguh Narutomo, "Program Penguatan Sistem Inovasi Daerah (SIDa) Sebagai Exit Strategy Program Nasional Pemberdayaan Masyarakat (PNPM)," Jurnal Bina Praja 06, No. 02 (2014): 143-156, https:// doi.org/10.21787/jbp.06.2014.143-156, hlm. 146.

24 Ilham Arief Sirajuddin, "Implementasi Kebijakan Pemerintah Daerah Dalam Pelayanan Publik Dasar Bidang Sosial Di Kota Makassar," Jurnal Ilmiah Ilmu Administrasi Publik 4, No. 1 (2016): 1-14, https:// doi.org/10.26858/JIAP.V4I1.1817, hlm. 4 . 
Nomor 12 Tahun 2011 tentang Pembentukan Peraturan PerundangUndangan, memberikan kewenangan bahwa Balitbangda berperan menyediakan naskah akademis berbasis ilmiah sebagai bahan baku perda dan perkada guna efektivitas dan meminimalisir kebijakan daerah yang bermasalah. ${ }^{25}$ Dalam materi muatan Pasal 8 ayat (1) Peraturan Pemerintah Nomor 12 Tahun 2017 tentang Pembinaan dan Pengawasan Penyelenggaraan Pemerintahan Daerah (PP Binwas Pemda), penelitian dan pengembangan dilaksanakan dengan tujuan peningkatan kualitas kebijakan dan program kerja pemerintah daerah yang akan diselenggarakan. Hasil penelitian dan pengembangan dijadikan dasar perumusan kebijakan penyelenggaraan pemerintahan daerah. ${ }^{26}$

Permendagri Nomor 17 Tahun 2016 tentang Pedoman Penelitian dan Pengembangan di Kementerian Dalam
Negeri dan Pemerintahan Daerah, menjelaskan bahwa pemerintah daerah dapat membentuk Balitbangda pada tingkat provinsi (BPP Provinsi) untuk melaksanakan fungsi kegiatan penelitian dan pengembangan (yang selanjutnya disebut kelitbangan) pada tingkat provinsi. Tugas BPP tersebut adalah menyusun kebijakan teknis, rencana, dan program kelitbangan, melaksanakan kelitbangan di lingkungan provinsi, dan mengeluarkan rekomendasi peraturan dan kebijakan kepada gubernur dan SKPD pada lingkungan provinsi. ${ }^{27}$

Peraturan Pemerintah Nomor 38 Tahun 2017 tentang Inovasi Daerah dengan ruang lingkup yang meliputi bentuk dan kriteria, pengusulan dan penetapan inisiatif, uji coba, penerapan, penilaian dan pemberian penghargaan, diseminasi dan pemanfaatan, pendanaan, informasi, pembinaan dan pengawasan terhadap inovasi daerah. ${ }^{28}$ Selanjutnya, Permendagri

23 Teguh Narutomo, “Program Penguatan Sistem Inovasi Daerah (SIDa) Sebagai Exit Strategy Program Nasional Pemberdayaan Masyarakat (PNPM)," Jurnal Bina Praja 06, No. 02 (2014): 143-156, https:// doi.org/10.21787/jbp.06.2014.143-156, hlm. 146.

24 Ilham Arief Sirajuddin, "Implementasi Kebijakan Pemerintah Daerah Dalam Pelayanan Publik Dasar Bidang Sosial Di Kota Makassar," Jurnal Ilmiah Ilmu Administrasi Publik 4, No. 1 (2016): 1-14, https:// doi.org/10.26858/JIAP.V4I1.1817, hlm. 4 .

25 Pasal 1 angka 11 Undang-Undang Nomor 12 Tahun 2011 tentang Pembentukan Peraturan PerundangUndangan.

26 Pasal 8 ayat (1) Undang-Undang Nomor 12 Tahun 2017 tentang Pembinaan Dan Pengazwasan Penyelenggaraan Pemerintahan Daerah.

27 Pasal 27 Peraturan Menteri Dalam Negeri Republik Indonesia Nomor 17 Tahun 2016 tentang Pedoman Penelitian Dan Pengembangan Di Kementerian Dalam Negeri Dan Pemerintahan Daerah.

28 Pasal 4 s.d. Pasal 34 Peraturan Pemerintah Nomor 38 Tahun 2017 tentang Inovasi Daerah. 
Nomor 104 Tahun 2018 tentang Penilaian dan Pemberian Penghargaan dan/atau Insentif Inovasi Daerah, mengatur bagaimana memberikan penghargaan kepada pemerintah daerah yang melakukan inovasi dan kreativitas dalam penyelenggaraan dan pengelolaan fungsi pemerintahan guna peningkatan kualitas kinerja pelayanan publik, meningkatkan pembangunan, pemberdayaan masyarakat, dan daya persaingan yang dimiliki daerah. ${ }^{29}$

Regulasi selanjutnya adalah Peraturan Bersama Menteri Negara Riset dan Teknologi Republik Indonesia dan Menteri Dalam Negeri Republik Indonesia Nomor 3 Tahun 2012 dan Nomor 36 Tahun 2012 tentang Penguatan Sistem Inovasi Daerah yang mengatur ruang lingkup penguatan sistem inovasi daerah. Hal tersebut meliputi kebijakan penguatan sistem inovasi daerah, penataan unsur sistem inovasi daerah dan pengembangan sistem inovasi daerah. ${ }^{30}$

Landasan hukum diperlukan sebagai cara untuk mengakomodir rekomendasi dan masukan hasil inovasi lembaga penelitian dan pengembangan pada level daerah dalam perencanaan pembangunan dan perumusan kebijakan pembangunan daerah. Berdasarkan beberapa perundang-undangan di atas, maka Pemerintah Kota Palopo untuk mengatur penyelenggaraan sistem inovasi daerah dalam sebuah peraturan daerah adalah hal yang sangat strategis, mulai dari sisi peningkatan kualitas pendidikan hingga sisi pembangunan sumber daya manusia di wilayah Kota Palopo.

d. Arah Pengaturan Peran Balitbangda dalam Rancangan Peraturan Daerah Badan Penelitian dan Pengembangan Daerah serta Inovasi Daerah

Dalam Raperda Kota Palopo yang akan dibuat harus mengakomodir semua kepentingan masyarakat Kota Palopo. Arah pengaturan Raperda tersebut harus mampu menjawab segala tantangan yang ada saat ini dan yang akan muncul di masa depan, sebagaimana visi dan misi Kota Palopo itu sendiri. Proses mewujudkan visi Kota Palopo tersebut, diperlukan upaya untuk melakukan perubahan dari berbagai masalah yang ada. Adapun kondisi yang harus dijawab oleh Balitbangda ke depan adalah : 1) Belum ada SDM fungsional litbang harus segera ditindaklanjuti dengan membuka kesempatan untuk seluruh

29 Pasal 2 Peraturan Menteri Dalam Negeri Nomor 104 Tahun 2018 tentang Penilaian Dan Pemberian Penghargaan Dan/Atau Insentif Inovasi Daerah.

30 Pasal 2 Peraturan Bersama Menteri Riset Dan Teknologi RI Dan Menteri Dalam Negeri RI No. 3 Tahun 2012 dan No. 36 Tahun 2012 tentang Penguatan Sistem Inovasi Daerah. 
ASN Balitbangda yang memenuhi syarat mengikuti diklat fungsional peneliti, perekayasa, maupun analis kebijakan; 2) Kemampuan Balitbangda dalam melaksanakan riset yang masih terbatas adalah hal yang sangat penting untuk segera ditingkatkan, mengingat layanan utama Balitbangda Kota Palopo yaitu, pelaksanaan penelitian dan pengembangan daerah. Hal ini dapat didorong dengan meningkatkan kerja sama dengan pihak perguruan tinggi maupun lembaga litbang kementerian/ lembaga; 3) Keterlibatan Balitbangda dalam penentuan kebijakan daerah yang masih rendah perlu didorong dengan koordinasi dan sosialiasi tentang peran Balitbangda dalam penyusunan kebijakan daerah. Lebih lanjut, dibutuhkan regulasi yang bersifat mengikat agar seluruh kebijakan daerah yang lahir harus melalui riset yang dikoordinasikan dengan Balitbangda Kota Palopo; 4) Balitbangda Kota Palopo belum memiliki perangkat litbang yang dapat menilai/mereview kualitas kelitbangan yang telah dihasilkan. Hal ini akan ditindaklanjuti dengan pembentukan Tim Majelis Pertimbangan, Tim Pengendali Mutu beserta unsur penunjang yang ditunjuk melalui SK Kepala Daerah dan melibatkan perangkat kelitbangan ini dalam perumusan kebijakan daerah; 5) Belum adanya jurnal yang dikelola Balitbangda untuk media publikasi perlu ditindaklanjuti melalui koordinasi dengan perguruan tinggi dan meningkatkan SDM aparatur Balitbangda melalui diklat pengelolaan jurnal; 6) Belum ada mekanisme/regulasi yang mendorong peran Balitbangda dalam mendorong sebuah rekomendasi menjadi kebijakan. Dibutuhkan komitmen dari seluruh jajaran Pemerintah Kota Palopo untuk bersamasama menyusun kebijakan berdasarkan rekomendasi yang telah dihasilkan melalui penelitian dan pengembangan selain itu kualitas rekomendasi yanng dihasilkan Balitangda harus bersifat implementatif, sehingga bisa langsung diterapkan sebagai kebijakan oleh pihak terkait; 7) Kemampuan Balitbangda untuk memfasilitasi perangkat daerah untuk berinovasi masih rendah dapat ditingkatkan dengan membentuk forum koordinasi kelitbangan daerah Kota Palopo di mana seluruh perangkat daerah didorong dan difasilitasi untuk berinovasi sehingga pelayanan publik semakin berkualitas; 8) Belum adanya kebijakan/regulasi/pedoman penyelenggaraan inovasi daerah berimplikasi pada adanya inkonsistensi arah kebijakan sistem inovasi daerah. Revisi roadmap (peta jalan) sistem inovasi daerah harus segera dilaksanakan dan seluruh stakeholders berkomitmen penuh melaksanakan apa yang telah ditetapkan pada roadmap tersebut; 9) Belum adanya regulasi daerah yang mempertegas peran Balitbangda dalam mengawal inovasi yang diusulkan menjadi kebijakan daerah disikapi dengan terus melaksanakan sinergi, pendampingan, dan koordinasi dengan perangkat daerah yang mengusulkan inovasi serta segera membuat komitmen bersama agar 
inovasi yang diusulkan dapat menjadi sebuah kebijakan. ${ }^{31}$

Aspek lain yang perlu untuk diperhatikan dan dikembangkan ke depannya adalah budaya birokrasi. Litbang daerah harus bisa menjadi tumpuan utama dalam perumusan kebijakan berdasarkan konsep efidence based policy. Pada perumusan kebijakan, sepatutnyamenggunakankajianatauriset yang dihasilkan oleh Balitbangda untuk melihat apakah suatu kebijakan yang dirumuskan akan memberikan manfaat bagi publik, kemudian apakah kebijakan tersebut dapat diimplementasikan atau tidak, sehingga budaya-budaya tersebut perlu untuk mulai diterapkan dengan baik dan menghasilkan kebijakan atau keputusan yang benar-benar bermanfaat bagi masyarakat. Dari hasil penelitian yang berupa inovasi inilah ke depannya bisa teraplikasikan. ${ }^{32}$

Ke depannya tingkat implementasi hasil penelitian pada aspek-aspek yang terkait ke dalam sebuah kebijakan yang dilaksanakan oleh pemerintah daerah bisa lebih ditingkatkan dan dikembangkan lagi. Semua harapan tersebut sejalan dengan permasalahan yang sedang dihadapi sekarang. Untuk itu diperlukan suatu instrumen regulasi yang dapat menyelesaikan dan memberi legitimasi dalam proses peningkatan kelitbangan dan inovasi daerah.

\section{SIMPULAN}

Peran Balitbangda sangat penting sebagai leading sector dalam memimpin segala kegiatan penelitian dan pengembangan serta inovasi daerah, tidak hanya di Kota Palopo, tetapi juga di daerah lain di Indonesia. Penelitian ini berhasil menemukan sasaran, jangkauan, dan arah pengaturan yang perlu diatur dalam Raperda tentang peran Balitbangda terkait kewenangan pemerintah daerah dalam kegiatan penelitian, pengembangan, serta pengembangan inovasi untuk menopang visi dan misi Kota Palopo 2018-2023. Sasaran penguatan peran Balitbangda adalah aspek inovasi sebagai stimulus percepatan lahirnya kesejahteraan masyarakat melalui peningkatan pelayanan publik, pemberdayaan, dan peran serta masyarakat. Hasil penelitian, pengembangan, dan inovasi tersebut dapat menjadi acuan dalam mengisi kekosongan hukum untuk menentukan kebijakan daerah serta mudah diimplementasikan karena

31 Hasil Focus Group Discussion dengan Stakeholder, “Urgensi Penguatan Balitbangda Dan Inovasi Daerah."

32 Bakhtiar Hajar, "Bureaucracy and Governance in Indonesia: Study on West Sulawesi Province," Procedia Economics and Finance 23, October 2014 (2015): 223-227, https://doi.org/10.1016/s22125671(15)00348-2, hlm 225. 
berbasis kebutuhan daerah dengan mempertimbangkan aspek filosofis, sosiologis, dan yuridis Kota Palopo. Maka dari itu, arah pengaturan dalam Raperda merupakan solusi untuk menghadapi semua tantangan yang ada saat ini dan yang akan datang dengan menciptakan ruang interaksi dan kolaborasi pelaku inovasi, mempercepat koordinasi dan intermediasi antara penyedia dan pengguna teknologi, serta memacu pemanfaatan hasil penelitian dan pengembangan dengan lebih optimal.

\section{DAFTAR PUSTAKA}

Artadi, Ibnu. "Hukum: Antara NilaiNilai Kepastian, Kemanfaatan Dan Keadilan." Hukum Dan Dinamika Masyarakat 4, No. 1 (2006): 6781. https://doi.org/http://dx.doi. org/10.36356/hdm.v4i1.362.

Djamaludin. Kepemimpinan Dan Inovasi. Jakarta: Erlangga, 2012.

Hajar, Bakhtiar. "Bureaucracy and Governance in Indonesia: Study on West Sulawesi Province." Procedia Economics and Finance 23, Oktober 2014 (2015): 223-227. https://doi. org/10.1016/s2212-5671(15)00348-2.

Hasil Focus Group Discussion dengan Stakeholder. "Urgensi Penguatan Balitbangda Dan Inovasi Daerah." 2019.
Hasil Focus Group Discussion. "Kondisi Saat Ini Kota Palopo." 2019.

Herdiana, Nana. Manajemen Bisnis Syariah Dan Kewirausahaan. Bandung: Pustaka Setia, 2013.

Ikram, Muhammad, dan Nur Fuady. "Siri ' Na Pacce Culture in Judge ' s Decision ( Study in Gowa, South Sulawesi Province )." Fiat Justisia 13, No. 3 (2019): 241-254. https://doi. org/10.25041/fiatjustisia.v13no3.1684.

Indonesia. Undang-Undang Nomor 12 Tahun 2011 tentang Pembentukan Peraturan Perundang-Undangan.

. Undang-Undang Nomor 12 Tahun 2017 tentang Pembinaan dan Pengawasan Penyelenggaraan Pemerintahan Daerah.

- Undang-Undang Nomor 11 Tahun 2019 tentang Sistem Nasional Ilmu Pengetahuan dan Teknologi.

. Peraturan Bersama Menteri Riset dan Teknologi Republik Indonesia dan Menteri Dalam Negeri Repbulik Indonesia Nomor 3 Tahun 2012 dan Nomor 36 Tahun 2012 tentang Penguatan Sistem Inovasi Daerah.

. Peraturan Menteri Dalam Negeri Republik Indonesia Nomor 17 Tahun 2016 tentang Pedoman Penelitian dan Pengembangan di Kementerian Dalam Negeri dan Pemerintahan Daerah. 
. Peraturan Pemerintah Nomor 38

Tahun 2017 tentang Inovasi Daerah.

. Peraturan Menteri Dalam Negeri

Nomor 104 Tahun 2018 tentang

Penilaian dan Pemberian Penghargaan dan/atau Insentif Inovasi Daerah.

Kim, Doo-Rae, and Jong-Han Yoon. "Decentralization, Government Capacity, and Environmental Policy Performance: A Cross-National Analysis." International Journal of Public Administration 41, No. 13 (October 3, 2018): 106-171. https:// doi.org/10.1080/01900692.2017.13189 17.

Muluk, M.R. Khairul. Knowledge Management (Kunci Sukses Inovasi Pemerintah Daerah). Malang: Banyumedia, 2008.

Narutomo, Teguh. “Program Penguatan Sistem Inovasi Daerah (SIDa) Sebagai Exit Strategy Program Nasional Pemberdayaan Masyarakat (PNPM)." Jurnal Bina Praja 6, No. 2 (2014): 143-156. https://doi. org/10.21787/jbp.06.2014.143-156.

Palopo, Pemerintah Kota. "Profil Kota Palopo." https://palopokota. go.id/page/visi-dan-misi. https:// palopokota.go.id/page/visi-danmisi.

Pepinsky, Thomas B., and Maria M. Wihardja. "Decentralization and
Economic Performance in Indonesia." Journal of East Asian Studies 11, No. 3 (2011): 337-371. https://doi. org/10.1017/S1598240800007372.

Purwanto, and Zakaria Lantang Sukirno. "Inovasi Produk Dan Motif Seni Batik Pesisiran." Jurnal Al-Azhar Indonesia Seri Pranata Sosial 1, No. 4 (2012): 217-229.

Said, M. Mas'ud. Birokrasi Di Negara Birokratis. Malang: UMM Press, 2007.

Setyosari, Punaji. Metode Penelitian Pendidikan Dan Pengembangan. Jakarta: Kencana, 2018.

Simandjuntak, Reynold. "Sistem Desentralisasi Dalam Negara Kesatuan Republik Indonesia Perspektif Yuridis Konstitusional." Journal de Jure 7, No. 1 (2016): 5767. https://doi.org/10.18860/j-fsh. v7i1.3512.

Simarmata, Jorawati. "Politik Hukum Restrukturisasi Pembentukan Perangkat Daerah Pasca Reformasi (Sekilas Tanggapan Terhadap Peraturan Pemerintah Nomor 18 Tahun 2016 Tentang Perangkat Daerah ) ( Political Law of PostReformation Local Government Officers Restructuring / Formin." Legislasi Indonesia 13, No. 4 (2016): 347-358. 
Sirajuddin, Ilham Arief. "Implementasi Kebijakan Pemerintah Daerah Dalam Pelayanan Publik Dasar Bidang Sosial Di Kota Makassar." Jurnal Ilmiah Ilmu Administrasi Publik 4, No. 1 (2016): 1-14. https://doi.org/10.26858/JIAP. V4I1.1817.

Susanto. " "60 Management Gems.” Kompas. 2010.

Yogi, Suwarno. Inovasi Di Sektor Publik. Jakarta: STIA LAN, 2008. 